\title{
A QUESTIONNAIRE BASED EVALUATION OF COLLEGE STUDENTS - PERCEPTION, FEEDBACK AND MARKETING IMPACT ON M.O.P. BAZAAR
}

\section{Monisha Murali*}

III year B.Sc student, Department of Food Science \& Management / M.O.P. Vaishnav College for Women, Chennai, Tamilnadu, India.

\section{ABSTRACT}

Background: The first M.O.P. Bazaar saw the light of day in 2009. Since its inception, it still serves as a platform for young entrepreneurs in understanding resource management and to run a business.

Objectives: The objective of the study attempts to evaluate the College student's perception, feedback and marketing impact on M.O.P. Bazaar conducted in a private college at Chennai.

Materials and Methods: 100 College students, who visited the M.O.P. Bazaar, were made to voluntarily participate in the study. They were administered a short questionnaire of 2 pages containing 25 questions to be solved in 10-15 minutes.

Results: Females (64\%) outnumbered the males in answering the questions. $76 \%$ were aware of the M.O.P. Bazaar through their friends with $60 \%$ favoring food stall as the most visited stall of the bazaar. Relatively major fraction (76\%) of students expressed that the price rate was reasonable. Finally on the overall experience about M.O.P. Bazaar, 52\% responded as very good and satisfactory.

Conclusion: In conclusion, the main findings of our current study was that, cultural and demographic factors can affect the over-all student's attitude and perception towards any bazaar along with food stall being the most visited stall of a bazaar.

KEYWORDS: College students, Chennai, M.O.P. Bazaar, Student's perception and feedback, Purchase trend.

Address for correspondence: Ms. Monisha Murali, III year B.Sc student, Department of Food Science \& Management / M.O.P. Vaishnav College for Women, Chennai, Tamilnadu, India.

E-Mail: srimuralihospital2012@gmail.com

\begin{tabular}{|l|ll|}
\hline \multicolumn{3}{|c|}{ Online Access and Article Informtaion } \\
\hline Quick Response code & \multicolumn{1}{|c|}{ International Journal of Integrative Medical Sciences } \\
& \multicolumn{1}{c}{ www.imedsciences.com } \\
\cline { 2 - 3 } & Received: 09-10-2017 & Accepted: 20-10-2017 \\
Dol: 10.16965/ijims.2017.115 & Reviewed: 09-10-2017 & Published: 03-11-2017 \\
\hline Source of Funding: Self & \multicolumn{2}{c}{ Conflicts of interest: None } \\
\hline
\end{tabular}

\section{BACKGROUND}

The much needed hands on experience for grooming the entrepreneurial skills of the students is given through the annual event the "M.O.P Bazaar", in one of the private colleges at Chennai. The first M.O.P Bazaar saw the light of day in 2009. The two day event functions as a platform to the building entrepreneurs, by exposing them to the real market scenario. Since its inception, it still serves as a platform for young entrepreneurs to understand resource manage- ment, identify suppliers and convince the customers to close a sale and to gain the confidence to run a business. The stalls offer a plethora of products ranging from art pieces, handicrafts, cosmetics, garments, footwear, leather products and mouth smacking food delicacies.

College student's behavior is a feeling of pleasure or disappointment resulting from comparing a product's perceived performance or outcome in relation to his or her expectations 
[1]. So college student's behavior is a function of perceived performance and expectations. Hence student's perception plays a role in the success of business strategy. College students buying behavior for food, accessories and others has always been influenced by sociodemographic factors like age, gender etc [2]. Cultural and demographic factors can affect the over-all student's attitudes towards any bazaar. It is accepted that the feedback from students serves as an effective tool in developing and evaluating student's satisfaction levels towards a good bazaar. The present study attempts to evaluate the student's perception, feedback and marketing impact on M.O.P. Bazaar conducted in a private college at Chennai.

\section{MATERIALS AND METHODS}

Study design: It was a cross sectional study.

Locus of study: The study was carried out in M.O.P - Bazaar, conducted by M.O.P. Vaishnav College for Women, at Chennai during the month of December 2016.

Sampling units: Students who visited M.O.P. Bazaar.

Sample size: Sample size is 100.

Ethics: The protocol and proforma for collection of data as well for the study was approved by the ethical committee.

Methodology: A short questionnaire of two pages containing a total of 25 questions was prepared to encourage college student's participation and also as a tool for data collection because this method assists to increase response rate. The designed questionnaires were distributed to the students within M.O.P. Bazaar and to be answered in $10-15$ minutes. The questionnaire included questions on 5 main categories:

1. Demographic profile of respondents.

2. Student awareness and most visited stall of M.O.P. Bazaar.

3. Response on ambiance, range, quality and customer service at M.O.P. Bazaar.

4. Effect of price level and overall purchase trend.

5. Overall experience about M.O.P. Bazaar.

The questionnaires contained both multiple choice questions (MCQ's) and open-ended type of questions. The purpose of the questionnaire was explained to students and also on how to complete the questionnaires. The participants were ensured confidentiality as well as anonymity of the information. Suggestions were also asked regarding the improvement of the bazaar.

Data / Statistical analysis: The data collected was analyzed using descriptive statistical principles and results were expressed as percentage.

\section{RESULTS}

Demographic profile of respondents: Social demographics of the respondents were the first element of the study. One hundred college students participated in this study. According to the data acquired (Table1) showed - female students $(64,64 \%)$ answered the questionnaire more compared to the males $(36,36 \%)$. The age groups of students were varied from $15-30$ years. Most of them were in the 15-20 age groups $(60,60 \%)$. The mean age was 21 years $(22.67 \%)$. More than half of the college students were from private university (65\%). The current study level of the students participated in the study were more of a Diploma level $(72,72 \%)$ than Degree level.

\section{Student awareness and most visited stall of}

M.O.P. Bazaar: These sections were to evaluate the level of awareness about M.O.P. Bazaar and the most visited stall by the students. Referring to Table 2 - most of the college students were aware of the M.O.P. Bazaar through their friends $(76,76 \%)$ followed by family $(16,16 \%)$ and remaining through other sources $(8,8 \%)$ and nil through newspaper. Regarding most visited stall, most of the participants favored food stall (60) followed by accessories (28). While the remaining 12 liked others and 8 were interested in the game stall. Further, on questioning about the number of visit to the M.O.P. Bazaar, 60 students responded as visited only once followed by 12 students who visited twice, while rest 28 of them had visited thrice to the bazaar.

Response on ambiance, range, quality and customer service at M.O.P. Bazaar: This was designed to find out the level of ambiance, range and quality of products along with the customer 
service at the bazaar. The results from this section were (Table 3): 76\% (76) participants responded that the ambiance of M.O.P. Bazaar was very attractive and visually appealing, $24 \%$ (24) responded as less attractive and less appealing while no one had a negative impression on the ambiance of the bazaar. Also majority (68) were of the opinion that the moving space was more spacious compared to 32 responding as less spacious. Concerning the range and quality of the products presented at M.O.P. Bazaar, comparable $(80,80 \%)$ number of students admitted that the products were good and hygienic. About $20 \%$ students mentioned that they were of average range and quality. Furthermore, when they were asked about the customer service, majority 52 (52\%) of them admitted they were satisfied with the service and was good, while 38 were opined it as average and remaining 10 responded as fair.

Effect of price level and overall purchase trend: These sections were to assess the student's tendency to buy products under different price levels. Among the college students (Table 4), 76\% had purchased more products, whereas $20 \%$ had made moderate purchases, followed by $4 \%$ that had at least one. Regarding the pricing of the products, majority of them (68\%) stated that the price list was clear, while remaining $28 \%$ were of the impression it was very clear, with only $4 \%$ stating as not clear. Relatively major fraction of participants (76\%) expressed the price rate as reasonable one, leaving remaining $24 \%$ as of high cost.

Overall experience about M.O.P. Bazaar: The final section of the questionnaire was based on the overall experience about M.O.P. Bazaar. Equal responses were obtained from college students (Fig 1) i.e., 28\% of them spent an hour while the other $28 \%$ of them stayed for 3 hours at the bazaar. While majority (44\%) of them stayed for a period of 2 hours. Of these hours spent at M.O.P. Bazaar (Fig 2), 96\% of participants opined it as happy hours while the rest $4 \%$ thought it as wasting hours. Concerning the entry ticket, 92\% favored it has reasonable compared to $8 \%$ as not reasonable. Finally on the overall shopping experience about M.O.P. Bazaar (Fig 3), 52\% responded it as very good and satisfactory. Remaining 40\% mentioned that it was good, while $8 \%$ responded, it as average.

Fig. 1: Showing the Hours distribution.

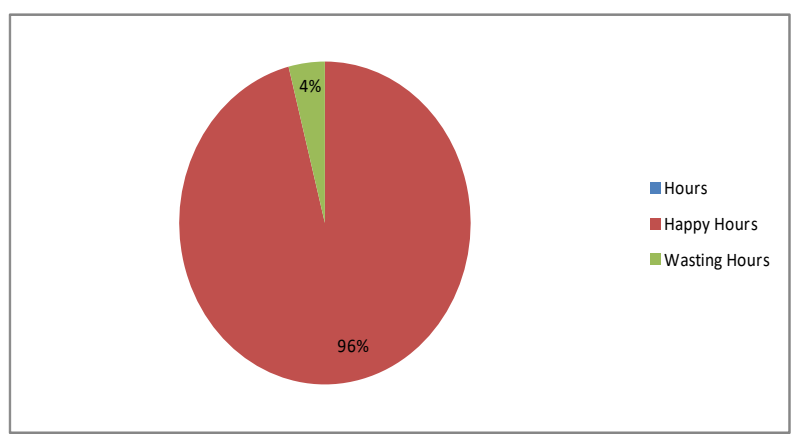

Fig. 2: Showing the no. of hours of spent by students.

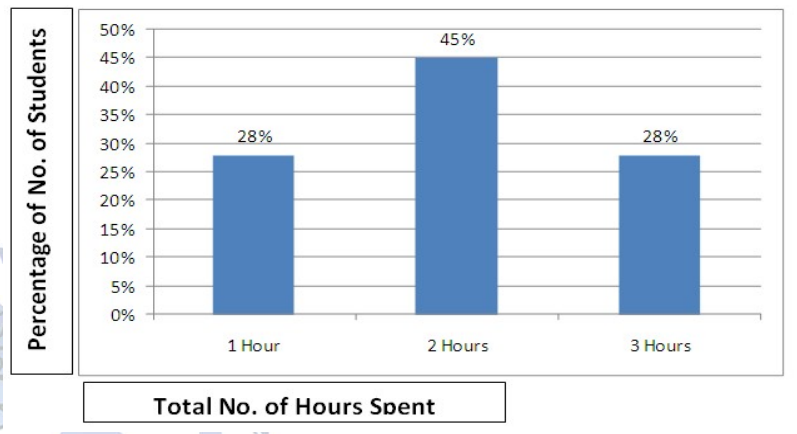

Fig. 3: Showing the Overall experience on MOP Bazaar.

Overall Expereince on MOP Bazaar

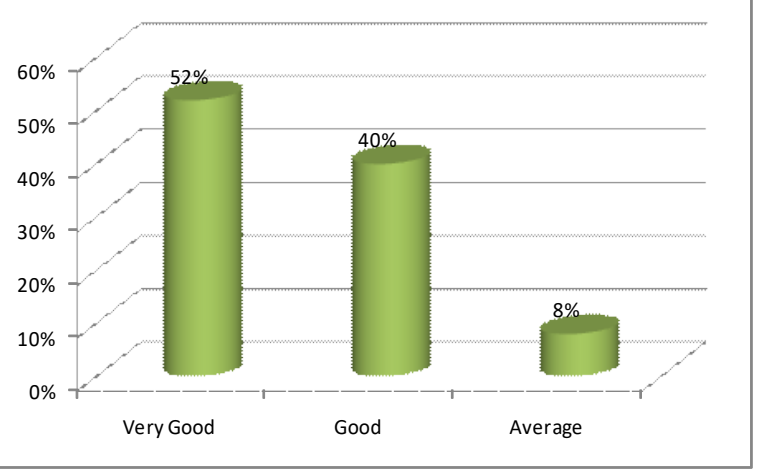

Table 1: Demographic profile of respondents.

\begin{tabular}{|c|c|c|}
\hline Demographic factors & $\begin{array}{c}\text { No. Of } \\
\text { respondents }\end{array}$ & Percentage \\
\hline \multicolumn{3}{|c|}{ Gender } \\
\hline Male & 36 & $36 \%$ \\
\hline Female & 64 & $64 \%$ \\
\hline \multicolumn{3}{|c|}{ Age of respondents } \\
\hline 15 - 20 years & 60 & $60 \%$ \\
\hline 21 - 25 years & 36 & $36 \%$ \\
\hline 26 - 30 years & 4 & $4 \%$ \\
\hline \multicolumn{2}{|c|}{ Type of University } \\
\hline Private & 65 & $65 \%$ \\
\hline Public & 35 & $35 \%$ \\
\hline \multicolumn{2}{|c|}{ Educational Background } \\
\hline Degree & 28 & $28 \%$ \\
\hline Diploma & 72 & $72 \%$ \\
\hline
\end{tabular}


Table 2: Student's awareness \& most visited stall of M.O.P. Bazaar.

\begin{tabular}{|c|c|c|c|c|c|c|c|c|}
\hline $\begin{array}{c}\text { No.of Respondents } \\
\& \%\end{array}$ & \multicolumn{4}{|c|}{ Awareness of M.O.P. Bazaar } & \multicolumn{4}{c|}{ Most visited stall of M.O.P.Bazaar } \\
\cline { 2 - 10 } & Friends & Family & Newspaper & Others & Food stall & Accessories & Game stall & Others \\
\hline Respondents & 76 & 16 & 8 & - & 60 & 28 & 8 & 12 \\
\hline Percentage & $76 \%$ & $16 \%$ & $8 \%$ & - & $60 \%$ & $28 \%$ & $8 \%$ & $12 \%$ \\
\hline
\end{tabular}

Table 3: Student's response on M.O.P. Bazaar.

\begin{tabular}{|c|c|c|c|c|c|c|c|c|c|}
\hline $\begin{array}{c}\text { No.of Respondents } \\
\& \%\end{array}$ & \multicolumn{3}{|c|}{ Ambiance } & \multicolumn{3}{c|}{ Range \& Quality } & \multicolumn{3}{c|}{ Customer Service } \\
\cline { 2 - 10 } & $\begin{array}{c}\text { Very } \\
\text { attractive }\end{array}$ & $\begin{array}{c}\text { Less } \\
\text { attractive }\end{array}$ & $\begin{array}{c}\text { Not } \\
\text { attractive }\end{array}$ & Good & Average & Poor & Good & Average & Fair \\
\hline Respondents & 76 & 24 & - & 80 & 20 & - & 52 & 38 & 10 \\
\hline Percentage & $76 \%$ & $24 \%$ & - & $80 \%$ & $20 \%$ & - & $52 \%$ & $38 \%$ & $10 \%$ \\
\hline
\end{tabular}

Table 4: Student's purchase Trend.

\begin{tabular}{|c|c|c|c|c|c|c|}
\hline \multirow{2}{*}{$\begin{array}{c}\text { No.of Respondents } \\
\& \%\end{array}$} & \multicolumn{3}{|c|}{ Purchase level } & \multicolumn{3}{c|}{ Pricing level } \\
\cline { 2 - 7 } & More & Moderate & Least & Clear & Very Clear & Not Clear \\
\hline Respondents & 76 & 20 & 4 & 68 & 28 & 4 \\
\hline Percentage & $76 \%$ & $20 \%$ & $4 \%$ & $68 \%$ & $28 \%$ & $4 \%$ \\
\hline
\end{tabular}

\section{DISCUSSION}

The hands on business experience through M.O.P Bazaar inspires the motivated entrepreneurs into - Identifying an opportunity, Building team work, Promoting optimum utilization of resources, Developing marketing and advertising skills, Formulating pricing strategies and Nurturing selling skills. In this fast world, college students are becoming more demanding and they definitely enjoy a unique shopping experience with speedy and accurate checkout. The most common places for shopping are supermarkets or hypermarkets followed by bazaars, departmental stores, small discount stores etc. The present study tried to relate the impact of college students in relation to their experiences in one of the bazaars conducted in Chennai during the month of December, but it does not give a complete picture of M.O.P. Bazaar. The information obtained from the evaluation includes the level of awareness, behavior and students response on ambiance, range, quality of the bazaar as well as on the effects of customer service, price level and purchase level trends among college students about M.O.P. Bazaar. The important suggestions received from the college students were regarding crowd management during peak hours and to conduct the M.O.P. Bazaar during the month of March, as the response will be better. Socio - demographic factors like age, gender, type of university and study level influences the college students on their behavior as well as purchase trend. The findings of our study were consistent with other studies [2,3]. Even though many Medias like T.V, newspaper are there, friends were the major source of information about the M.O.P. Bazaar in the present study. College student's awareness on M.O.P. Bazaar in Chennai is much lower than that in other parts of Chennai, as it is being conducted within the city limits of Chennai. Taking any big bazaar into consideration, food stall forms the most important component of the bazaar. In this study, more than half of the students (60\%) visited food stall of the M.O.P. Bazaar. This finding can be compared to one of the study conducted in Malaysia [4].

A general impression among the public is that, a good layout and service creates a better impression and positive attitude towards a bazaar. From the study it is observed that college students had good \& positive opinions towards the ambiance, range, quality of products and customer service at M.O.P. Bazaar. The findings are consistent with studies $[3,5]$ which found the significance of better service quality to increase customer satisfaction.

As the college students are not an earning member of the family and still depend on their parents for shopping, the purchase trends among them may vary and also may be affected by the labeled prices. The study showed that the majority of the students found out the prices 
of the products were reasonable. The overall purchase trend was great (76\%). Higher preference of purchase trends was also reported in earlier studies [6]. But in one the studies [7], they have showed the fact that consumers' response to different types of marketing strategies is the major question to be answered. At the end of the study, the overall experience of the college students of M.O.P. Bazaar was satisfactory and was independent of their genders.

However considering the fact that these college students are all young adults who are pursuing higher levels of education in tertiary institution there are still much room for improvement and further futuristic research about such subjective issue should be taken up.

Limitations: The limitations of this study were the time frame whereby in depth research of the topic was not possible and due to long questionnaire, student's response was not prompt to assess the student's actual perception and marketing impact on M.O.P. Bazaar. This could be due to biased information as most of the college students may not give the correct information. The study was confined to only one bazaar in Chennai. Perhaps for future study, expansion of sampling population should include other bazaars in Chennai as well.

\section{CONCLUSION}

In conclusion, the main findings of our current study was that, cultural and demographic factors can affect the over-all student's attitude and perception towards any bazaar along with food stall being the most visited stall of a bazaar. The student's feedback about the quality and customer service, serves as an array of effective ideologies in organizing a good bazaar. Apart from this, the study also addresses issues related to purchase trends among college students and there is a definite need for modifications of bazaars so as to make it more attractive and purchasable.

\section{ACKNOWLEDGEMENT}

I wish to express my sincere gratitude and respect to our Principal, Dr. Lalitha Balakrishnan, M.O.P. Vaishnav College for Women, Chennai, India for her enormous support and encouragement. I am grateful and thankful to Dr. E. Nirupama, Associate Professor, Department of Commerce, for her guidance, kind co-operation and motivation in bringing out this article. My sincere appreciation and thanks are extended to all participants from both the public and private universities who were directly and indirectly involved in this study.

\section{REFERENCES}

[1]. Duggani Yuvaraju, Duggani Subramanyam, S.Durga Rao. A Study on Customer Satisfaction towards Food Bazaar in Bangalore. Global Journal of Commerce \& Management Perspective. 2014; 3(4); 238-244.

[2]. Maruyama.M and L.V. Trung. The nature of informal food bazaars: Empirical results for Urban Hanoi, Vietnam. Journal of Retailing and Consumer Services. 2010;17(1):1-9.

[3]. Sailaja V, Suryanarayana A, Surya Narayana R. Emerging Trends in Food Retailing: An Empirical Study on Customer Satisfaction. International Journal of Innovative Research \& Development. 2016; 5(2):127-136.

[4]. Ishak, Nor Khomar, Khursiah Abd Aziz, and Rohaizah Abdul Latif. Typology of night markets in Malaysia. Journal of Case Research in Business and Economics 2012;4:1-10.

[5]. Yasser Mahfoozi. Relationship between Service Quality and Customer Satisfaction in Hypermarkets of Saudi Arabia. International Journal of Marketing Studies. 2014; 6(4); 11-22.

[6]. Satish kumar Singh, Pratyush Tripathi, P K Jain. Buying Behavior of Customers in Organized Food Retailing - A Review. Current Trends in Technology and Science. 2011; 3(1): 6-15.

[7]. Olson J.C., Peter J.P. Consumer Behavior and Marketing strategy, 8 th International edition, Mcgraw Hills.

How to cite this article: Monisha Murali.A QUESTIONNAIRE BASED

EVALUATION OF COLLEGE STUDENTS - PERCEPTION, FEEDBACK AND

MARKETING IMPACT ON M.O.P. BAZAAR.Int J Intg Med Sci

2017;4(6):522-526. DOI: 10.16965/ijims.2017.115 